\title{
Effect of microgrooved surface topography on osteoblast maturation and protein adsorption
}

\begin{tabular}{|r|l|}
\hline Journal: & Journal of Biomedical Materials Research: Part A \\
\hline Manuscript ID: & JBMR-A-14-1013.R1 \\
\hline Wiley - Manuscript type: & Original Article \\
\hline Complete List of Authors: & $\begin{array}{r}\text { de Luca, Alba; University of Cambridge, Department of Engineering } \\
\text { Zink, Mareike; University of Leipzig, Faculty of Physics and Earth Sciences, } \\
\text { Institute for Experimental Physics I, Soft Matter Physics Division } \\
\text { Weidt, Astrid; University of Leipzig, Faculty of Physics and Earth Sciences, } \\
\text { Institute for Experimental Physics I, Soft Matter Physics Division } \\
\text { Mayr, Stefan; University of Leipzig, Leibniz Institute for Surface } \\
\text { Modification (IOM), Translational Centre for Regenerative Medicine and } \\
\text { Faculty of Physics and Earth Sciences } \\
\text { Markaki, Athina; University of Cambridge, Engineering }\end{array}$ \\
\hline Keywords: & $\begin{array}{l}\text { Fibronectin, Grooved Substrates, Osteoblast Cells, Surface Topography, } \\
\text { Contact Guidance }\end{array}$ \\
\hline & \\
\hline
\end{tabular}




\section{Effect of microgrooved surface topography on osteoblast maturation and protein} adsorption

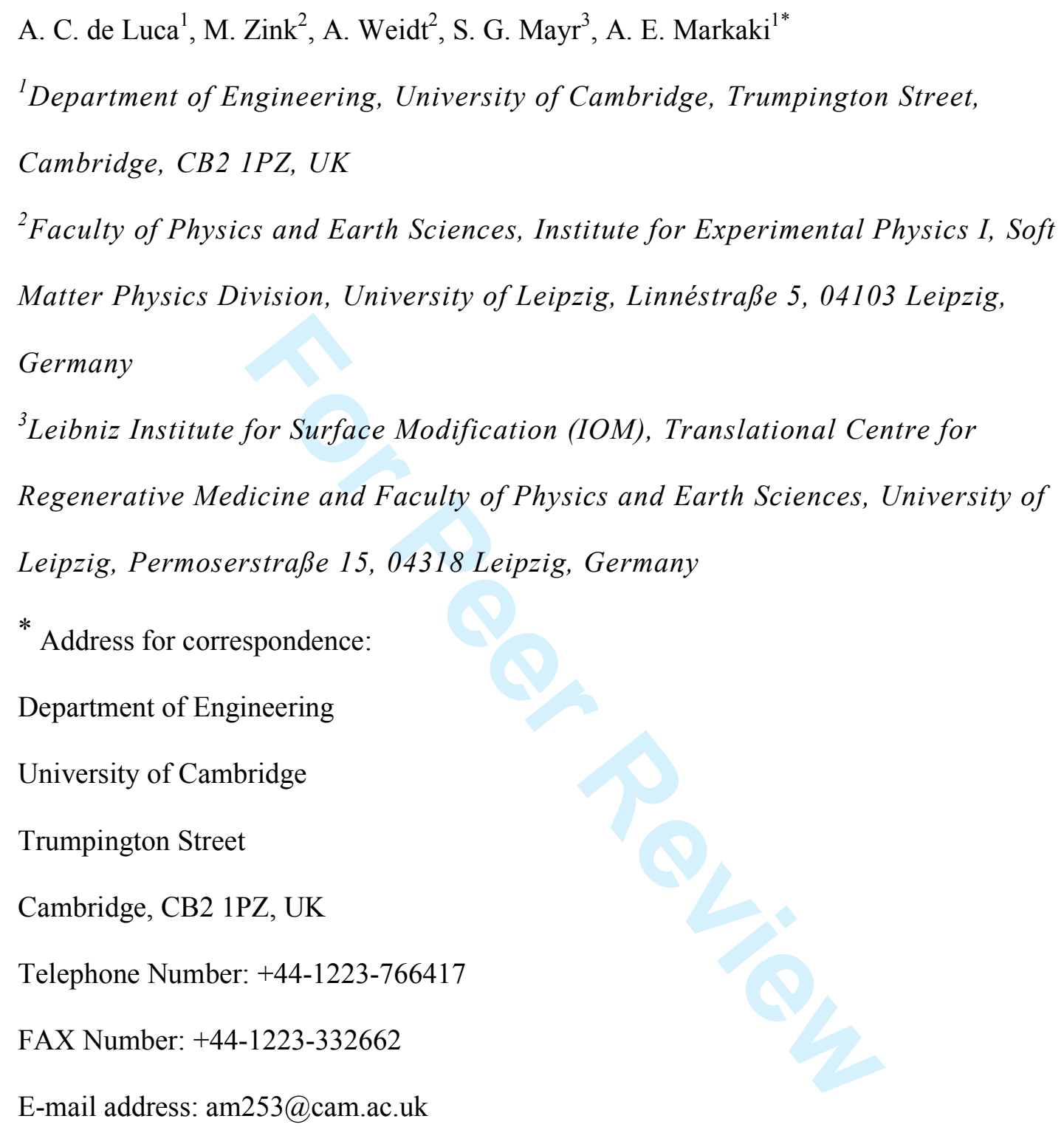




\begin{abstract}
Microgrooved surfaces have been used extensively to influence cell contact guidance.

Guiding cell growth, extracellular matrix deposition, and mineralization is important for bone implant longevity. In this study, we investigated the osteoblast response to microgrooved metallic surfaces in serum-supplemented medium. Groove spacing was comparable to the spread osteoblast size. Focal adhesions were observed to confine to the intervening ridge/groove boundaries. Osteoblasts bridged over the grooves and were unable to conform to the concave shape of the underlying grooves. Microgrooved surfaces induced higher osteoblast proliferation and metabolic activity after 14 days in osteogenic medium compared to as-received surfaces, resulting in higher mineralization, and alignment of cell-secreted collagen after 28 days. To establish whether preferential cell attachment at the ridge/groove boundaries was influenced by the adhesion proteins contained in the serum supplemented media, fluorescently-labelled fibronectin was adsorbed onto the microgrooved substrates at low concentrations, mimicking the concentrations found in blood serum. Fibronectin was found to selectively adsorb onto the ridge/groove boundaries, the osteoblast focal adhesion sites, suggesting that protein adsorption may have influenced the cell attachment pattern.
\end{abstract}

\title{
Keywords
}

Fibronectin, Grooved Substrates, Osteoblast Cells, Surface Topography, Contact Guidance.

\section{Introduction}

Longitudinal parallel grooves have been widely investigated due to their ability to induce cell alignment, known as "contact guidance" ${ }^{1}$, which is the ability of the cell to use topographical cues for orientation and migration. Studies into the efficacy of these channels suggest that cell behaviour is affected in a microgroove dimension-dependent manner $\left(\right.$ eg $\left.^{2-9}\right)$. Morphological 
cell changes do not necessarily alter phenotypic expression. For example, when human connective tissue progenitor cells were cultured on polydimethylsiloxane (PDMS) substrates with U-shape microgrooves ( $11 \mu \mathrm{m}$ deep, $45 \mu \mathrm{m}$ wide, separated by $5 \mu \mathrm{m}$ wide ridge), the microgroove topography had no effect on cell differentiation ${ }^{10}$. Similar observations were made when myoblasts were cultured on polycarbonate substrates with square microgrooves (5 $\mu \mathrm{m}$ deep, $5-75 \mu \mathrm{m}$ wide, separated by $5-75 \mu \mathrm{m}$ wide ridge) in terms of myogenic differentiation ${ }^{11}$. However, not all cell types are insensitive to microgrooves, suggesting that modulation of phenotypic expression may be cell type specific ${ }^{11}$. For example, osteoblasts seeded on titanium substrates with V-shape microgrooves (5 and $10 \mu \mathrm{m}$ deep, 30/ $60 \mu \mathrm{m}$ wide, separated by $30 / 60 \mu \mathrm{m}$ ridge) were found to express higher levels of alkaline phosphatase (ALP) compared to smooth surfaces ${ }^{4}$. Similar observations involving osteoblast cells are reported elsewhere (reviewed by Anselme ${ }^{1}$ ).

Although the effects of surface topography on cells have been studied extensively, it is not possible to draw some clear conclusions due to the huge range of surfaces, pattern geometries and cell types employed. Furthermore, in many studies, the effect of surface topography is not truly distinguished from that of surface chemistry. Research has focused on understanding the effect of surface topography on cell response, but often the interactions between proteins present in the cellular surrounding, i.e. extracellular matrix (ECM) or blood, and the substrates are not considered. Specific cell responses are in fact promoted when proteins containing the arginine-glycine-aspartic acid (RGD) motif, such as fibronectin or vitronectin, are adsorbed onto the biomaterial surface prior to cell adhesion. The adhesion multifunctional glycoproteins of the ECM, such as fibronectin and vitronectin, and their receptors have been found to play an important role in osteoblast differentiation and mineralization ${ }^{12-14}$. In particular, fibronectin is a protein dimer, consisting of two nearly identical polypeptide chains. The central-binding domain has been repeatedly reported to play the most important 
role in the osteogenicity of bone cells. Adding anti-fibronectin antibodies to the culture medium ${ }^{12,13}$ was correlated with a reduced osteoblast adhesion and mineralization. It was observed that the inhibition of the osteogenic gene expression in the early phase of osteogenesis was reversible, with deposition of calcified nodules occurring when the fibronectin-osteoblast interactions were reactivated ${ }^{12}$. Furthermore, fibronectin expression has been observed in vivo at bone surfaces and in vitro at the periphery of nodules, confirming the importance of this protein in osteogenesis ${ }^{12}$.

It has been found that micro- ${ }^{15}$ and nano-scale ${ }^{16,17}$ topographical cues can stimulate changes in protein adsorption. For example, on "rough" (at the micrometer level) grit-blasted surfaces, proteins have been found to accumulate on peaks rather than valleys ${ }^{15}$, possibly due to higher accessibility of these sites and higher electrostatic forces ${ }^{18}$. However, following adsorption, proteins were found to migrate into the valleys ${ }^{18}$, concealing or exposing specific sites that may alter the biological function of the protein. Therefore, it could be hypothesized that preferential protein adsorption may affect "cell contact guidance".

In this study, osteoblast interactions with patterned substrates were investigated in serumsupplemented medium, thus containing adhesion promoting fibronectin proteins. Parallel grooves, with widths comparable to the spread osteoblast size, were produced by photoetching on $316 \mathrm{~L}$ stainless steel substrates. Cell morphology, proliferation and mineralization, and collagen production were investigated. Protein adsorption experiments, using fluorescently-labelled fibronectin, were carried out to investigate how the grooves spatially control protein adsorption. Fibronectin adsorption was influenced by the local topography. It was hypothesized that the observed cell attachment pattern on the microgrooves may have been influenced by preferential adsorption of adhesion-promoting proteins. 


\section{Materials \& Methods}

\section{$\underline{2.1 \text { Material and Specimen Preparation }}$}

Mirror-finish 316L austenitic stainless steel sheets ( $1 \mathrm{~mm}$ thick), supplied by Aalco (Roundtree Way, Mousehold Lane, Norwich, NR7 8SR, UK), were used for this study. Microgrooves were photoetched on the surface of 316L samples by Precision Micro (Vantage Way, Birmingham, B24 9GZ, UK). The samples had a square cross-section with a side length of $8 \mathrm{~mm}$. In addition, $9.5 \mathrm{~mm}$ diameter discs were cut out of the as-received sheets using a punch press. The latter served as a control surface.

For material characterization, the discs were ultrasonically cleaned, sequentially, for $5 \mathrm{~min}$ in acetone, ethanol and distilled water, and then dried in oven at $60^{\circ} \mathrm{C}$. For biological investigations, discs were further sterilized at $160{ }^{\circ} \mathrm{C}$ for 2 hours.

\subsection{Topographic Characterization}

\subsubsection{Differential Interference Contrast (DIC) Microscopy}

Surface topography was characterized with a DIC microscope equipped with an Enhanced Focal Imaging (EFI) control for 3D surface mapping (Olympus BX51m, Japan). Images were acquired at 10x magnification.

\subsubsection{Scanning Electron Microscopy (SEM)}

For SEM analysis, samples were mounted on aluminium stubs with double-sided carbon tape. Images were acquired using an Evo MA 15 scanning electron microscope (Zeiss, UK) with an accelerating voltage of $14 \mathrm{kV}$ at $1000 \mathrm{x}$ magnification.

\subsubsection{Analysis of Micropatterns}

Cross-sections of the patterned surfaces were impregnated in Acri-Kleer cold mounting resin (MetPrep Ltd, UK), ground with a series of SiC papers (MetPrep Ltd, UK) and polished with alumina micro-particles. Samples were observed using an optical light microscope (Leica 
DMLM, UK) at 20x and 50x magnifications, with bright-field illumination. Pattern dimensions were measured using the ImageJ software (National Institute of Health, US, ${ }^{19}$ ).

\subsubsection{X-ray Photoelectron Spectroscopy (XPS)}

XPS data were acquired using a Kratos Axis Ultra DLD (delay-line detector) system, equipped with a monochromatized Al Ka X-ray source (spot size $700 \times 300 \mu \mathrm{m}^{2}$ ). For survey spectra, a pass energy of $160 \mathrm{eV}$, a dwell time of $0.1 \mathrm{~s}$ and a step size of $1 \mathrm{eV}$ were used. For high resolution spectra, the pass energy and the step size were changed to $40 \mathrm{eV}$ and $0.1 \mathrm{eV}$ respectively. A measurement time of 60 s per sweep was used instead of a fixed dwell time and the number of sweeps was adjusted for optimum element quantification.

\subsubsection{Atomic Force Microscopy (AFM)}

Surface roughness was measured in tapping mode using a Bruker Dimension Icon AFM equipped with a Nanoscope V controller. The scanned area was $1 \times 1 \mu \mathrm{m}^{2}$. Post-processing, including roughness evaluation, was performed using the Scanning Probe Image Processor (SPIP) 6.0.6 software, applying polynomial fits $\left(1^{\text {st }}\right.$ order) and $1^{\text {st }}$ order line-wise corrections to all images.

\section{$\underline{2.3 \text { Cell Culture Studies }}$}

\subsubsection{Sourcing and Culture of Cells}

Primary foetal human osteoblasts (fHObs; 406-05f, European Collection of Cells Cultures (ECACC)) were selected for the present study and used at the $5^{\text {th }}$ passage for all the experiments. fHObs were maintained and subcultured in growth medium containing McCoy's 5A medium (Thermo Scientific, UK), $10 \%$ foetal bovine serum (FBS, Invitrogen, UK), $1 \%$ penicillin-streptomycin (Sigma, UK) and $30 \mathrm{mg} / \mathrm{ml}$ vitamin-C (L-Ascorbic Acid Phosphate Magnesium Salt n-Hydrate, Wako GmbH).

Cells were seeded in growth medium at a density of 10,000 cells $/ \mathrm{cm}^{2}$ on each substrate (in triplicate per type) and each experiment was repeated three times $(n=3)$. After 4 days, growth 
medium was replaced to osteogenic medium, supplemented with $10 \mathrm{nM}$ dexamethasone (Sigma, UK) and $2.5 \mathrm{mM} \beta$-glycerophosphate (Sigma, UK) to stimulate fHOb differentiation.

\subsubsection{Cell Metabolic Activity and Proliferations}

Cell metabolic activity was assessed using the AlamarBlue assay (ADB Serotec, UK), at several time points $(1,3,7,10,14$ days), monitoring the same cell-seeded samples over time. At each time point, $10 \%(\mathrm{v} / \mathrm{v})$ of AlamarBlue solution was added to each well and cells were incubated for 4 hours at $37^{\circ} \mathrm{C}$. Following incubation, $100 \mu \mathrm{L}$ of the supernatant were transferred in triplicate to a black 96-well plate. Fluorescence was recorded using a FluoStar Optima plate reader (BMG Labtech, Germany) at $530 \mathrm{~nm}$ excitation and $590 \mathrm{~nm}$ emission. Samples were then washed with sterile Hank's Balanced Salt Solution (HBSS; Invitrogen, UK). Fresh medium was added to each well before incubation for the next time point. The percentage of reduction of AlamarBlue is given by

$$
\% \text { reduction of AlamarBlue }=\frac{S_{A B}^{x}-S_{A B}^{\text {control }}}{S_{A B}^{100 \% \text { reduced }}-S_{A B}^{\text {control }}}
$$

where $S_{A B}^{x}$ is the AlamarBlue fluorescence signal of the sample at day $x, S_{A B}^{100 \% \text { reduced }}$ is the signal of the $100 \%$ reduced form of AlamarBlue and $S_{A B}^{\text {control }}$ is the signal from the control: the culture medium supplemented with 10\% AlamarBlue dye. The $100 \%$ reduced form of AlamarBlue was produced by autoclaving controls.

Cell proliferation was evaluated using the CyQUANT Cell Proliferation Assay (Invitrogen, UK). At each time point (1, 3, 7, 14 days), the medium was aspirated and the samples were frozen at $-80^{\circ} \mathrm{C}$ until measurement. After thawing, a CyQUANT lysis buffer was added to each well according to the manufacturer's instructions. The multi-well plates were gently agitated and the cell lysate was transferred to a black 96-well plate. The CyQUANT dye solution was added to the cell lysate in equal volume. Fluorescence was then recorded at 480 
$\mathrm{nm}$ excitation and $520 \mathrm{~nm}$ emission. Fluorescence readings were converted into cell numbers through a standard curve and then normalized to surface area.

\subsubsection{Cell Morphology}

Cell morphology was investigated using scanning electron and confocal microscopy. For SEM, fHObs were seeded on each substrate at a density of 10,000 cells $/ \mathrm{cm}^{2}$ and they were cultured up to 7 days. After 1, 3 and 7 days, cell-seeded samples were carefully washed in sterile PBS and fixed in $2.5 \%$ glutaraldehyde (Sigma, UK) solution in PBS for 30 minutes at $4{ }^{\circ} \mathrm{C}$. Samples were washed in PBS and dehydrated in graded ethanol series $(50 \%, 70 \%, 90$ $\%, 100 \%$ ). They were then rinsed with hexamethyldisilazane (HMDS; Alfa Aesar, US) and left to air-dry overnight in a fume hood before mounting on stubs and gold sputtering for SEM analysis. Images were acquired at 1000x magnification using an Evo MA 15 scanning electron microscope with an accelerating voltage of $15 \mathrm{kV}$.

For confocal microscopy, 5,000 cells $/ \mathrm{cm}^{2}$ were seeded on each surface in triplicate to characterize cell morphology via image analysis using a cell mask dye. At each time point (1, 3, 7 days), cell-seeded samples were carefully washed with sterile PBS before fixation in $4 \%$ paraformaldehyde (PFA) solution (Affymetrix, US) for 15 minutes at room temperature. Samples were then washed again in PBS and permeabilized in $0.1 \%$ Triton-X solution in PBS for 15 minutes at room temperature. Samples were finally washed in PBS, incubated with a cytoplasmatic stain (HCS CellMask green, Life Technology, UK; $2 \mu \mathrm{g} / \mathrm{ml}$ ) for 30 minutes at room temperature in the dark, and washed again before mounting on glass slides for imaging. Images were captured with a 20x objective using an inverted fluorescence microscope (CKX41 Olympus). Around 100-150 cells were analyzed per time point and the experiment was repeated three times $(n=3)$. Images were processed using Image J and the following parameters were evaluated: cell area, aspect ratio and orientation.

\subsubsection{Focal Adhesions and Cytoskeletal Organization}

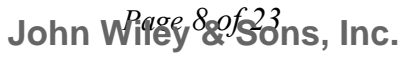


Cell-seeded samples $\left(10,000 \mathrm{cell} / \mathrm{cm}^{2}\right)$ were fixed after 1 and 3 days of culture in $4 \%$ PFA solution for 15 minutes at room temperature after being carefully washed in sterile PBS. Samples were washed again in PBS and immersed in a permeabilizing buffer containing 0.1 $\%$ Triton-X and $0.1 \%$ Tween in PBS for 30 minutes at room temperature. They were then carefully washed in PBST solution (0.05\% Tween in PBS) and non-specific antigens were blocked with $5 \%$ goat serum in PBST for 30 minutes at room temperature. For the detection of focal adhesions, the Anti-Vinculin antibody (hVIN-1, Sigma, UK; 1:400) was applied for 1 hour at room temperature, after which samples were rinsed with PBST. The samples were then dark-incubated with the secondary antibody (Alexa Fluor 594 goat anti-mouse IgG, Life Technologies, UK; 1:500) for 1 hour at room temperature and rinsed again with PBST. Cells were finally dark-incubated with phalloidin (Alexa Fluor 488, Life Technologies, UK; 1:40) for 30 minutes at room temperature and rinsed with PBST. Prior to imaging, samples were mounted on glass coverslips with DAPI mounting medium (Life Technologies, UK).

Fluorescence images were acquired using a Confocal Laser Scanning Microscopy (CLSM) system (Leica DMIRE2, UK) with a 63x objective immersed in water.

\subsubsection{Cell Mineralization}

Cell mineralization was investigated after 14, 21 and 28 days in culture using Alizarin Red staining. Briefly, at each time point, cell-seeded samples were washed with sterile PBS and fixed in $70 \%$ ethanol solution for 1 hour at $4{ }^{\circ} \mathrm{C}$. Samples were rinsed three times with milliQ water and stained in $40 \mathrm{mM}$ Alizarin Red solution $(\mathrm{pH}=4.1)$ for 10 minutes at room temperature. Samples were carefully washed with distilled water until water turned clear and images were captured using a light optical microscope (Olympus BX51m).

For optical density measurements, a $10 \%$ acetic acid solution was added to each well and samples were incubated for 30 minutes at room temperature, continuously agitating on an orbital shaker to help cell monolayer detachment. The cells and the acetic acid solution were 
transferred into microcentrifuge tubes and vortexed. The tubes were then heated to $85^{\circ} \mathrm{C}$ for 10 minutes, cooled down to room temperature and centrifuged at 20,000 g for 15 minutes. The $\mathrm{pH}$ of the solution was neutralized with $10 \%$ ammonium hydroxide. The solution was then transferred in triplicate to a new transparent 96-well plate and the absorbance was recorded at $405 \mathrm{~nm}$. Results were converted into moles of Alizarin Red through a standard curve and then normalized with surface area.

\section{$\underline{2.4 \text { Collagen Deposition }}$}

After 28 days in culture, cell-seeded samples were carefully washed in sterile PBS and fixed in $4 \%$ paraformaldehyde solution for 30 minutes at room temperature. Samples were washed with deionized water twice and incubated in a $0.2 \%$ phosphomolybdic acid (Sigma, UK) solution for 2 minutes at room temperature. They were then incubated in a $0.1 \%$ Picrosirius Red solution (BDH Laboratory Supplies, UK) in saturated picric acid (May \& Baker ltd, UK) for 1 hour at room temperature under a fume hood. Samples were finally rinsed in deionized water until a clear solution was obtained, differentiated in a $0.01 \%$ hydrochloric acid for 2 minutes and washed twice in water. Images were acquired using a CLSM system equipped with an argon ion laser emitting at $514 \mathrm{~nm}$, using a $63 \mathrm{x}$ objective immersed in water.

\section{$\underline{2.5 \text { Protein Adsorption }}$}

Microgrooved samples were cleaned as described in $§ 2.1$. HiLyte Fluor ${ }^{\mathrm{TM}} 488$ labelled fibronectin from bovine plasma (Tebo-Bio $\mathrm{GmbH}$, Offenbach, Germany) was resuspended in milliQ water to $1 \mathrm{mg} / \mathrm{ml}$. Samples were coated with a diluted fibronectin solution of 0.1

$\mu \mathrm{g} / \mathrm{cm}^{2}$ final concentration and allowed to air dry overnight at room temperature. Fibronectin adsorbed on the substrates was imaged using a fluorescence microscope (502 nm excitation and $527 \mathrm{~nm}$ emission wavelengths) and overlaid with bright field microscopy images of the same surface areas. All images were acquired at 10x magnification and captured using a Zeiss 
AxioCam ICm1 Rev.1 camera mounted on a Zeiss Axio Scope MAT (Jena, Germany).

Experiments were repeated three times.

\subsection{Statistical Analysis}

For all studies, averages of three independent experiments $(n=3)$, with three tested samples per type, were expressed as the arithmetic mean \pm standard deviation (SD). Statistical significance between groups was evaluated by two-way ANOVA with Bonferroni's post-test (Prism 5, GraphPad software, Version 5.03). Levels of significance were expressed as $p$ values vs. controls (as-received surfaces) $\left({ }^{a} p<0.05,{ }^{b} p<0.01,{ }^{c} p<0.001\right)$.

\section{Results}

\section{$\underline{3.1 \text { Surface Topography }}$}

Figure 1 (a) shows a schematic representation of the cross-sectional views of the micropatterns. The design dimensions of the patterns are shown in Table I. The patterns are designated as " $40 \mu \mathrm{m}$ ", " $80 \mu \mathrm{m}$ " and " $120 \mu \mathrm{m}$ ” on the basis of their pitch dimensions. Figures 1 (b)-(d) show respectively 3D DIC maps, cross-sectional and top views of the as-received and microgrooved surfaces. From Figure 1 and Table 1, it can be seen that the ridge and the groove dimensions, and also the groove depth, increased with increasing pitch size (the $40 \mu \mathrm{m}$ patterns had adjacent grooves - no ridges). The average surface roughness values associated with the grooves increased with increasing pitch size as illustrated in Table 2.

\subsection{Surface Chemistry}

The composition and chemical states of the as-received and patterned surfaces are indicated in Table 3, as determined by high resolution XPS region spectra. Generally, they reveal only minor differences, as discernible from the relative peak intensities. Photoetching results in lower $\mathrm{C}-\mathrm{C}, \mathrm{C}-\mathrm{H}$ and $\mathrm{Cl} 2 \mathrm{p}$ peak intensities, presumably due to removal of carbonaceous surface deposits, as well as lower $\mathrm{Cr} 2 \mathrm{p} 3$ peaks for both metallic and oxide states. A slight 
increase of the $\mathrm{C}-\mathrm{C}, \mathrm{C}-\mathrm{H}$ and $\mathrm{Cl} 2 \mathrm{p}$ peaks with pattern pitch size was observed which might be attributed to the presence of etch residues from the photoetching process, thus reflecting differences in etching time.

\section{$\underline{3.3 \text { Cell Metabolic Activity and Proliferation }}$}

Cell metabolic activity and proliferation were assessed using the AlamarBlue (Figure 2 (a)), and the CyQuant (Figure 2 (b)) assays respectively. Figures 2 (a) and 2 (b) show that statistically significant results were only observed at day 14. In particular, cells seeded on patterned surfaces exhibit statistically higher metabolic activity $\left({ }^{a} p<0.05\right)$ and cell numbers $\left({ }^{a} p<0.05,{ }^{b} p<0.01\right)$ than those on the as-received surface. No significant differences were observed between the different patterns.

\section{$\underline{3.4 \text { Cell Morphology and Alignment }}$}

SEM images showing top views of the cell-seeded surfaces after 1, 3 and 7 days in growth medium are illustrated in Figure 3. It can be seen that cell shape is strongly guided by the grooves. On all patterns, cells aligned along the long axis of the grooves whereas on the asreceived surfaces they were randomly oriented. The vast majority of cells spread from one groove/ridge boundary to the other by bridging the groove; a very small number of cells preferred to reside inside the grooves.

Differences in cell morphology were investigated using image analysis of fluorescent images of cells cultured on all surfaces after 1, 3 and 7 days in culture. As illustrated in Figures 4 (a)(c), cell morphology was characterized in terms of cell area, aspect ratio and orientation. The latter is expressed as the angular distribution of cell orientation along the long axis of the patterns.

Results show that cells cultured on as-received surfaces exhibit higher projected areas compared to patterned surfaces (Figure 4 (a)). After 1 and 3 days of culture, there are some differences in cell-projected areas between the different patterns, with the $120 \mu \mathrm{m}$ patterns 
showing higher cell areas, which may be due to the fact that cells have to bridge a wider groove spacing. Differences between microgrooved and as-received surfaces became statistically significant after 7 days of culture $\left({ }^{c} p<0.001\right)$, while no significant differences were observed between the different patterns.

The cell aspect ratio is a measure of cell polarization and is defined as the ratio between the maximum and the minimum length of the cell. Figure 4 (b) shows that cells were polarized on the patterned surfaces due to the contact guidance induced by the grooves. At each time point, measured values were statistically different compared to cells cultured on as-received surfaces, onto which cells spread uniformly with no preferential alignment $\left({ }^{a} p<0.05,{ }^{b} p<\right.$ 0.01 and $\left.{ }^{c} p<0.001\right)$. No significant changes in the cell aspect ratio were observed with culture time. The aspect ratio values were about 5 and 2 for the patterned and as-received surfaces respectively.

Figure 4 (c) shows the angular distributions of the cell orientation on the different substrates after 1 day of culture. The data are plotted using a circular graph, superimposed on the patterns, showing the angle of the long axis of each cell in relation to the groove direction. On the as-received surfaces, the angle is being measured relative to an arbitrary axis. As expected, cells show a random distribution on the as-received surfaces whereas, on the patterned surfaces, a clear contact guidance effect can be observed. The $80 \mu \mathrm{m}$ patterns had the broader distribution but also the highest fraction of cells along the long axis of the groove whereas the $120 \mu \mathrm{m}$ patterns exhibit the sharpest distribution. The orientation angles were mostly of the order of $10-15^{\circ}$.

\section{$\underline{3.4 \text { Cytoskeletal Organization and Formation of Focal Adhesions }}$}

Cells were stained against actin and vinculin in order to investigate respectively the F-actin cytoskeleton organization and the formation of focal adhesions on the different surfaces. At day 1 (Figures 5 (a)-(d)), stress fibers aggregated in a filamentous configuration on all 
surfaces. F-actin filaments were aligned along the $40 \mu \mathrm{m}$ patterns, partially oriented along the $80 \mu \mathrm{m}$ and $120 \mu \mathrm{m}$ patterns, and randomly distributed on the as-received substrates. At day 3 (Figure 5 (e)-(h)), F-actin filaments were oriented parallel to the long axis of the grooves on all patterned surfaces and remained randomly oriented on the as-received surface. On the 80 and $120 \mu \mathrm{m}$ patterns, focal adhesions were observed along the groove/ridge boundaries and the ridges (Figures $5(\mathrm{~g})$ and $(\mathrm{h})$ ). On the $40 \mu \mathrm{m}$ patterns, a smaller number of focal adhesions were observed (Figure 5 (f)). This is probably because the available contact area adjacent to the grooves is much smaller (no intervening ridges). On all patterns, very few / no focal adhesions were observed along the grooves as the cells preferred to span across the grooves. This is probably attributed to the high rigidity of the osteoblast cytoskeleton, causing cells to bridge across the grooves without attaching conformally to the bottom of the grooves. Since there were very few / no focal adhesions inside the grooves it can be postulated that differences in groove depth and roughness between the patterns, shown in Tables 1 and 2, haven't played important roles in the initial cell response.

\section{$\underline{3.5}$ Cell Mineralisation}

fHObs were fixed after 14, 21 and 28 days of culture in osteogenic medium and stained with Alizarin Red for nodule detection. No signs of mineralization were observed after 14 days of culture. However, cells were able to deposit calcium after 21 days of culture with mineralization increasing over time. Figures 6 (a)-(d) show very distinct Alizarin Red-stained nodular areas on all surfaces after 28 days. All patterns induced higher mineralization compared to as-received surfaces as measured with acetic acid extraction (Figure 6 (e); ${ }^{b} p<$ $\left.0.01 ;{ }^{c} p<0.001\right)$, with particular formation of calcified nodules inside the grooves. Comparison between patterns suggests that the $120 \mu \mathrm{m}$ patterns induce less mineralization than the 40 and $80 \mu \mathrm{m}$ patterns (Figure $6(\mathrm{e})$ ).

$\underline{\text { 3.6 Collagen Deposition }}$

John Wirgey \& \& of 
Representative fluorescence confocal images illustrated in Figure 7 show higher production of collagen on patterned substrates compared to the as-received surface. Higher collagen deposition occurred inside the grooves, with less matrix detected on the ridges. Cell-secreted collagen was preferentially aligned along the patterns suggesting that the microgrooved substrates stimulate higher production of ECM, with a well-organised structure.

\subsection{Adsorption of Fibronectin on the Groove Edges}

The adsorption of fluorescently-labelled fibronectin on the micropatterned substrates was investigated using low fibronectin concentrations to mimic the concentrations found in blood serum ${ }^{20}$. As illustrated in Figure 8, fibronectin adsorbs predominantly onto the ridge/groove boundaries. Almost no fibronectin was detected onto the ridges or grooves. The same adsorption pattern was observed in all patterns. It should be noted that in the $40 \mu \mathrm{m}$ patterns (Figure 8 (a)), the bright areas correspond to the grooves since it was not possible to focus at the ridges, whereas in Figures 8 (c) and (e) the bright areas correspond to the ridges of the 80 $\mu \mathrm{m}$ and $120 \mu \mathrm{m}$ patterns.

\section{Discussion}

In this study, patterned 316L stainless steel substrates with different pitch-groove designs were investigated; with groove spacing comparable to the spread osteoblast size. A surface specific-technique, XPS, showed that the micro-grooved surfaces exhibit similar surface chemistry to the as-received surfaces.

Osteoblast response and collagen deposition were monitored in serum conditions for up to 4 weeks. Osteoblasts were found to preferentially attach at the groove/ridge boundaries. They were unable to conform to the groove curvature, resulting in bridging the distance between two adjacent pitches. Grooves induced a clear contact guidance effect on the cells as they aligned along the groove direction. Conversely, cells on as-received surfaces showed no 
directional preference. In agreement with previous work ${ }^{21}$, as cells polarized, their total projected area was reduced compared to those attached on the as-received surface. As proposed in a previous study ${ }^{22}$, micro-discontinuities on substrates could result in the creation of adhesive and non-adhesive areas for cell attachment. Furthermore, focal adhesions were found to mostly confine to the groove/ridge boundaries. Statistically significant metabolic activities were only observed at day 14 but these differences are probably attributed to differences in cell numbers. After 21 days in culture, calcium minerals were deposited within the ECM, indicative of osteogenesis. At day 28, all patterns induced statistically higher mineralization compared to as-received surfaces. Collagen deposition was investigated after 28 days in culture, suggesting higher ECM production on patterned substrates as compared to the as-received surfaces, with increased protein secretion within the microgrooves. No significant differences were observed between the different patterns in terms of cell proliferation, metabolism, mineralization, and collagen production.

To explain the differences observed in cell response between patterned and non-patterned surfaces, an investigation was carried out to determine whether adhesion proteins contained in the culture media, like fibronectin, are also involved.

The adhesion multifunctional glycoproteins of the ECM, such as fibronectin and vitronectin, and their receptors have been found to play an important role in osteoblast differentiation and mineralization ${ }^{4,12-14,23}$. Fibronectin is one the most important adhesive proteins of the ECM, consisting of two monomeric units joined together by disulphide bonds close to the carboxyl terminus of the protein to form the characteristic dimeric structure. It is well known that sulphur forms strong complexes with metal elements and its stability on stainless steel after adsorption has been demonstrated via XPS analysis ${ }^{24}$.

To investigate protein-surface interactions, fibronectin adsorption experiments were carried out using concentrations similar to those found in blood serum ${ }^{20}$. Fibronectin molecules were 
found to aggregate at the groove/ridge boundaries where a higher concentration of vinculin, a protein of cellular focal adhesion sites, was also observed. Almost no fibronectin was detected onto the ridges or grooves. The same adsorption pattern was observed in all patterns.

The process of protein adsorption on implant surfaces is still not well understood and several competing events are considered to be involved. It has been proposed ${ }^{25}$ that the preferred adsorption of proteins on grooved substrates could be associated with wetting anisotropy, by which a droplet would stick to the edges of grooves and stretch along the groove long axis.

Similar findings were obtained via numerical simulations on grooved nanostructures ${ }^{18}$. These simulations ${ }^{18}$ showed that, under physiological conditions, convex edges show better accessibility for proteins due to a greater surrounding liquid volume and increased electrostatic forces. Compared to smooth surfaces, topographical features can offer more active sites for protein adsorption ${ }^{16,26,27}$; this phenomenon was particularly observed for fibronectin ${ }^{28}$.

In summary, our study demonstrates that the fibronectin-substrate interaction that occurs almost instantly after seeding, may affect the long-term osteoblast response, in particular mineralization (as previously suggested ${ }^{23}$ ) and collagen deposition.

\section{Conclusions}

In this study, the osteoblast behaviour on micropatterned substrates was investigated. Focal adhesions were found to confine to the groove/ridge boundaries. Grooved substrates induced higher osteoblast proliferation and metabolic activity after 14 days in culture compared to asreceived surfaces, resulting in higher mineralization and production of cell-secreted collagen after 28 days. Varying the groove spacing and depth, over the range tested, had no noticeable effect on cell response. To establish whether the substrate-protein interactions could have played a role in the observed cell response, fluorescently-labelled fibronectin, a mediator for 
cell adhesion, was adsorbed onto microgrooved metallic substrates at concentrations similar to those found in blood serum. Fibronectin was found to selectively adsorb onto the groove/ridge boundaries, the osteoblast focal adhesion sites. This preferential attachment is most likely due to better accessibility of available sites for protein adhesion. The results confirm the significance of the spatial distribution of surface-bound proteins in cell attachment, shape and maturation, and, potentially, in guiding tissue integration on an implant surface.

\section{Acknowledgments}

This research was supported by the European Research Council (Grant No. 240446). XPS, AFM and fibronectin experiments were carried out at the IOM Leipzig and the University of Leipzig, and were funded in parts by the German Federal Ministry of Education and Research (BMBF 1315883), the European Union and the Free State of Saxony (SAB 100121467).

The authors would like to acknowledge Dr. Jeremy Skepper from the Department of Physiology, Development and Neuroscience, of Cambridge University, for his assistance with the Picrosirius Red Staining. The authors are particularly grateful to Dr. J. Gerlach and A. Landgraf of IOM Leipzig for carrying out the XPS and AFM measurements respectively, and for useful discussions.

\section{References}

1. Anselme K. Osteoblast adhesion on biomaterials. Biomaterials 2000;21(7):667-81.

2. Curtis A, Wilkinson C. Topographical control of cells. Biomaterials 1997;18(24):1573-1583.

3. Nikkhah M, Edalat F, Manoucheri S, Khademhosseini A. Engineering microscale topographies to control the cell-substrate interface. Biomaterials 2012;33(21):5230-46. 
4. Lee MH, Oh N, Lee SW, Leesungbok R, Kim SE, Yun YP, Kang JH. Factors influencing osteoblast maturation on microgrooved titanium substrata. Biomaterials 2010;31(14):3804-3815.

5. Brunette DM, Kenner GS, Gould TRL. Grooved titanium surfaces orient growth and migration of cells from human gingival explants. Journal of Dental Research $1983 ; 62(10): 1045-1048$.

6. Denbraber ET, Deruijter JE, Smits HTJ, Ginsel LA, Vonrecum AF, Jansen JA. Effect of parallel surface microgrooves and surface-energy on cell-growth. Journal of Biomedical Materials Research 1995;29(4):511-518.

7. Chou LS, Firth JD, Uitto VJ, Brunette DM. Substratum surface-topography alters cellshape and regulates fibronectin messenger-RNA level, messenger-RNA stability, secretion and assembly in human fibroblasts. Journal of Cell Science 1995;108:15631573.

8. Biggs MJP, Richards RG, McFarlane S, Wilkinson CDW, Oreffo ROC, Dalby MJ. Adhesion formation of primary human osteoblasts and the functional response of mesenchymal stem cells to $330 \mathrm{~nm}$ deep microgrooves. Journal of the Royal Society Interface 2008;5(27):1231-1242.

9. Bettinger CJ, Langer R, Borenstein JT. Engineering Substrate Topography at the Micro- and Nanoscale to Control Cell Function. Angewandte Chemie-International Edition 2009;48(30):5406-5415.

10. Mata A, Boehm C, Fleischman AJ, Muschler G, Roy S. Analysis of connective tissue progenitor cell behavior on polydimethylsiloxane smooth and channel micro-textures. Biomedical Microdevices 2002;4(4):267-275. 
11. Charest JL, Garcia AJ, King WP. Myoblast alignment and differentiation on cell culture substrates with microscale topography and model chemistries. Biomaterials 2007;28(13):2202-2210.

12. Moursi AM, Damsky CH, Lull J, Zimmerman D, Doty SB, Aota S, Globus RK. Fibronectin regulates calvarial osteoblast differentiation. J Cell Sci 1996;109 ( Pt 6):1369-80.

13. Puleo DA, Bizios R. Mechanisms of fibronectin-mediated attachment of osteoblasts to substrates in vitro. Bone Miner 1992;18(3):215-26.

14. Schneider G, Burridge K. Formation of focal adhesions by osteobalsts adhering to different substrata. Exp Cell Res 1994;214:264-269.

15. Pegueroles M, Aparicio C, Bosio M, Engel E, Gil FJ, Planell JA, Altankov G. Spatial organization of osteoblast fibronectin matrix on titanium surfaces: Effects of roughness, chemical heterogeneity and surface energy. Acta Biomaterialia 2010;6(1):291-301.

16. Richert L, Variola F, Rosei F, Wuest JD, Nanci A. Adsorption of proteins on nanoporous Ti surfaces. Surface Science 2010;604(17-18):1445-1451.

17. Scopelliti PE, Borgonovo A, Indrieri M, Giorgetti L, Bongiorno G, Carbone R, Podesta A, Milani P. The Effect of Surface Nanometre-Scale Morphology on Protein Adsorption. Plos One 2010;5(7).

18. Elter P, Lange R, Beck U. Electrostatic and Dispersion Interactions during Protein Adsorption on Topographic Nanostructures. Langmuir 2011;27(14):8767-8775.

19. Schneider CA, Rasband WS, Eliceiri KW. NIH Image to ImageJ: 25 years of image analysis. Nature Methods 2012;9(7):671-675.

20. Hayman EG, Ruoslahti E. Distribution of fetal bovine serum fibronectin and endogenous rat cell fibronectin in extracellular matrix. J Cell Biol 1979;83(1):255-9. 
21. Oakley C, Brunette DM. The Sequence of Alignment of Microtubules, Focal Contacts and Actin-Filaments in Fibroblasts Spreading on Smooth and Grooved Titanium Substrata. Journal of Cell Science 1993;106:343-354.

22. Karuri NW, Nealey PF, Murphy CJ, Albrecht RM. Structural Organization of the Cytoskeleton in SV40 Human Corneal Epithelial Cells Cultured on Nano- and Microscale Grooves. Scanning 2008;30(5):405-413.

23. Brunner M, Millon-Fremillon A, Chevalier G, Nakchbandi I, Mosher D, Block M. Osteoblast mineralization requires beta1 integrin/ICAP-1-dependent fibronectin. J Cell Biol 2011;194:307-322.

24. Galtayries A, Warocquier-Clerout E, Nagel M, Marcus P. Fibronectin adsorption on Fe-Cr alloy studied by XPS. Surf Interface Anal 2006;38:186-190.

25. Fadeeva E, Schlie S, Koch J, Chichkov BN. Selective Cell Control by Surface Structuring for Orthopedic Applications. Journal of Adhesion Science and Technology 2010;24(13-14):2257-2270.

26. Dolatshahi-Pirouz A, Jensen T, Kraft DC, Foss M, Kingshott P, Hansen JL, Larsen AN, Chevallier J, Besenbacher F. Fibronectin Adsorption, Cell Adhesion, and Proliferation on Nanostructured Tantalum Surfaces. Acs Nano 2010;4(5):2874-2882.

27. Peng WT, Qiao ZM, Zhang Q, Cao XD, Chen XF, Dong H, Liao JW, Ning CY. Micropatterned $\mathrm{TiO} 2$ nanotubes: fabrication, characterization and in vitro protein/cell responses. Journal of Materials Chemistry B 2013;1(28):3506-3512.

28. Hao L, Lawrence J, Phua YF, Chian KS, Lim GC, Zheng HY. Enhanced human osteoblast cell adhesion and proliferation on 316 LS stainless steel by means of CO2 laser surface treatment. Journal of Biomedical Materials Research Part B-Applied Biomaterials 2005;73B(1):148-156. 


\section{Figure Captions}

Fig. 1. Surface topography of micro-patterned surfaces: $40 \mu \mathrm{m}$ (left), $80 \mu \mathrm{m}$ (centre) and 120 $\mu \mathrm{m}$ (right). (a) Schematic representation of cross-sectional views $(R=$ Ridge, $G=$ Groove, $P=$ Pitch and $D=$ Groove Depth); (b) high-contrast 3-D DIC images; (c) cross-sectional (optical microscopy) and (d) top (SEM) views.

Fig. 2. fHOb response onto as-received (AR) and patterned surfaces. (a) Cell metabolic activity expressed as \% of AlamarBlue reduction; (b) cell proliferation as cell number. All results are normalized per $\mathrm{cm}^{2}\left({ }^{a} p<0.05 ;{ }^{b} p<0.01\right)$.

Fig. 3. SEM images showing fHObs attached on the different surfaces at day 1 (a-d), 3 (c-h) and 7 (i-1). From left to right: as-received (AR), $40 \mu \mathrm{m}, 80 \mu \mathrm{m}$ and $120 \mu \mathrm{m}$ surfaces.

Fig. 4. Morphological analysis of fHObs cultured on as-received (AR) and patterned surfaces. The following parameters were evaluated using image analysis of fluorescent images: (a) cell area; (b) aspect ratio; (c) cell orientation after 1 day of culture expressed as the angular distribution of cell orientation along the long axis of the patterns. Concentric circles indicate the percentage of cells. Statistical differences were defined as ${ }^{a} p<0.05,{ }^{b} p<0.01$ and ${ }^{c} p<$ 0.001 .

Fig. 5. Fluorescence confocal images of fHObs cultured for 1 (a-d) and 3 (e-h) days on the different surfaces. From left to right: as-received (AR), $40 \mu \mathrm{m}, 80 \mu \mathrm{m}$ and $120 \mu \mathrm{m}$ surfaces. Phalloidin488, AlexaFluor594 and DAPI respectively stained actin fibers (green), vinculin focal adhesions (red) and cell nuclei (blue). The dotted white lines drawn on the fluorescence images (f-h) show the location of the grooves $(G)$ and ridges $(R)$ on the different patterned surfaces.

Fig. 6. Optical microscopy images showing calcified nodules stained with Alizarin Red, on (a) as-received (AR); (b) $40 \mu \mathrm{m}$; (c) $80 \mu \mathrm{m}$; (d) $120 \mu \mathrm{m}$ surfaces. fHObs were cultured in osteogenic medium for 28 days prior fixation. (e) Quantification of Alizarin Red, obtained 
with acetic acid extraction, as a function of culture time. Results are normalized per $\mathrm{cm}^{2}\left({ }^{b} p<\right.$ $\left.0.01 ;{ }^{c} p<0.001\right)$

Fig. 7. Confocal microscopy images showing collagen deposition after 28 days of culture in osteogenic medium on (a) as-received (AR); (b) $40 \mu \mathrm{m}$; (c) $80 \mu \mathrm{m}$; (d) $120 \mu \mathrm{m}$ surfaces. Collagen was stained with Picrosirius Red. Images were acquired with a laser-scanning confocal microscope equipped with an argon ion laser emitting at $514 \mathrm{~nm}$.

Fig. 8. Confocal microscopy images showing fibronectin adsorption onto the micropatterned surfaces: (a, b) $40 \mu \mathrm{m}$; (c, d) $80 \mu \mathrm{m}$; (e, f) $120 \mu \mathrm{m}$. The left-hand column shows the patterned surfaces and the adsorbed fibronectin, while the right-hand column shows the adsorbed fibronectin only. In the $40 \mu \mathrm{m}$ patterns, the bright areas correspond to the grooves, whereas in the $80 \mu \mathrm{m}$ and $120 \mu \mathrm{m}$ patterns, the bright areas correspond to the ridges. 
Table 1. Pattern design dimensions. The $40 \mu \mathrm{m}$ patterns had adjacent grooves i.e. no ridges between the grooves.

\begin{tabular}{lccc}
\hline Pattern & $\mathbf{4 0} \boldsymbol{\mu \mathbf { m }}$ & $\mathbf{8 0} \boldsymbol{\mu m}$ & $\mathbf{1 2 0} \boldsymbol{\mu m}$ \\
\hline Pitch, $\boldsymbol{P}(\boldsymbol{\mu m})$ & $39.56 \pm 0.28$ & $79.99 \pm 0.24$ & $119.00 \pm 0.80$ \\
Ridge, $\boldsymbol{R}(\boldsymbol{\mu \mathbf { m }})$ & -- & $29.84 \pm 0.39$ & $39.67 \pm 0.15$ \\
Groove, $\boldsymbol{G}(\boldsymbol{\mu m})$ & $39.56 \pm 0.28$ & $50.15 \pm 0.38$ & $79.33 \pm 1.40$ \\
Groove Depth, $\boldsymbol{D}(\boldsymbol{\mu m})$ & $5.31 \pm 0.21$ & $15.37 \pm 0.04$ & $20.66 \pm 1.10$ \\
\hline
\end{tabular}

John Wiley \& Sons, Inc. 
1

2

3

4

5

6

7

8

9

10

11

12

13

14

15

16

17

18

19

20

21

22

23

24

25

26

27

28

29

30

31

32

33

34

35

36

37

38

39

40

41

42

43

44

45

46

47

48

49

50

51

52

53

54

55

56

57

58

59

60

Table 2. Groove average roughness $(R \mathrm{a})$ values (scan area $1 \times 1 \mu^{2}$ ), as measured by AFM.

\begin{tabular}{ccc}
\hline \multicolumn{3}{c}{ Average roughness (Ra) $(\mathbf{n m})$} \\
\hline $\mathbf{4 0} \boldsymbol{\mu m}$ & $\mathbf{8 0} \boldsymbol{\mu m}$ & $\mathbf{1 2 0} \boldsymbol{\mu m}$ \\
\hline $5.11 \pm 1.92$ & $5.90 \pm 3.15$ & $7.44 \pm 4.31$ \\
\hline
\end{tabular}

John Wiley \& Sons, Inc. 
Table 3. Chemical state composition of as-received (AR) and micropatterned 316L stainless steel surfaces.

\begin{tabular}{|c|c|c|c|c|c|c|c|c|c|}
\hline \multirow[b]{2}{*}{$\begin{array}{l}\text { XPS } \\
\text { peak }\end{array}$} & \multirow[b]{2}{*}{$\begin{array}{l}\text { Chemical } \\
\text { state }\end{array}$} & \multicolumn{2}{|c|}{$\mathbf{A R}$} & \multicolumn{2}{|c|}{$40 \mu \mathrm{m}$} & \multicolumn{2}{|c|}{$80 \mu \mathrm{m}$} & \multicolumn{2}{|c|}{$120 \mu \mathrm{m}$} \\
\hline & & $\begin{array}{c}\text { Ch. } \\
\text { State } \\
(\mathbf{A t} \%)\end{array}$ & $\begin{array}{l}\text { Elem. } \\
\text { (At\%) }\end{array}$ & $\begin{array}{c}\text { Ch. } \\
\text { State } \\
(\mathbf{A t} \%) \\
\end{array}$ & $\begin{array}{l}\text { Elem. } \\
(\text { At\%) }\end{array}$ & $\begin{array}{c}\text { Ch. } \\
\text { State } \\
(\text { At\%) }\end{array}$ & $\begin{array}{l}\text { Elem. } \\
\text { (At\%) }\end{array}$ & $\begin{array}{c}\text { Ch. } \\
\text { State } \\
(\text { At\%) }\end{array}$ & $\begin{array}{l}\text { Elem. } \\
\text { (At\%) }\end{array}$ \\
\hline $\mathrm{Zn} 2 \mathrm{p}$ & element & 0.72 & 0.72 & 0.56 & 0.56 & 0.60 & 0.60 & 0.23 & 0.23 \\
\hline $\mathrm{Cu} 2 \mathrm{p}$ & element & 1.86 & 1.86 & 1.36 & 1.36 & 1.70 & 1.70 & 1.45 & 1.45 \\
\hline \multirow[t]{2}{*}{$\mathrm{Fe} 2 \mathrm{p} 3$} & element & 0.04 & 5.94 & 0.74 & 6.61 & 0.16 & 4.99 & 0.12 & 6.28 \\
\hline & $\mathrm{Fe}_{2} \mathrm{O}_{3}$ (oxide) & 5.90 & & 5.87 & & 4.83 & & 6.16 & \\
\hline Mn 2p1 & $\mathrm{MnO}_{\mathrm{x}}$ (oxide) & 0.91 & 0.91 & 2.05 & 2.05 & 1.45 & 1.45 & 1.13 & 1.13 \\
\hline \multirow[t]{2}{*}{$\mathrm{Cr} 2 \mathrm{p} 3$} & element & 0.04 & 1.11 & 0.54 & 3.81 & 0 & 2.90 & 0.97 & 3.14 \\
\hline & $\mathrm{Cr}_{2} \mathrm{O}_{3}$ (oxide) & 1.07 & & 3.27 & & 2.90 & & 2.17 & \\
\hline \multirow[t]{2}{*}{ O 1s } & metal oxide & 15.09 & 39.93 & 16.06 & 42.31 & 13.29 & 40.30 & 15.79 & 42.95 \\
\hline & other & 24.84 & & 26.25 & & 27.01 & & 27.16 & \\
\hline $\mathrm{N} 1 \mathrm{~s}$ & nitride & 1.01 & 1.01 & 1.11 & 1.11 & 1.44 & 1.44 & 1.15 & 1.15 \\
\hline \multirow[t]{3}{*}{ C 1s } & C-C, C-H & 32.47 & 46.30 & 26.72 & 39.49 & 27.61 & 42.9 & 28.18 & 38.63 \\
\hline & $\mathrm{C}-\mathrm{OH}$ & 6.23 & & 5.09 & & 10.40 & & 5.18 & \\
\hline & carbonate & 7.60 & & 6.68 & & 4.89 & & 5.27 & \\
\hline $\mathrm{Cl} 2 \mathrm{p}$ & element & 0.27 & 0.27 & 0.57 & 0.57 & 0.62 & 0.62 & 0.98 & 0.98 \\
\hline Si 2s & element & 1.31 & 1.31 & 2.24 & 2.24 & 2.61 & 2.61 & 3.30 & 3.30 \\
\hline $\mathrm{P} 2 \mathrm{p}$ & element & 0.65 & 0.65 & 0.67 & 0.67 & 0.49 & 0.49 & 0.62 & 0.62 \\
\hline Ni $2 p 3$ & element & -- & -- & 0.22 & 0.22 & -- & -- & 0.14 & 0.14 \\
\hline
\end{tabular}


(a)

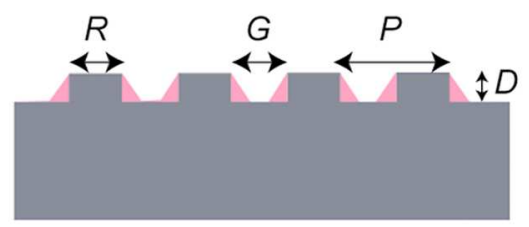

(b)

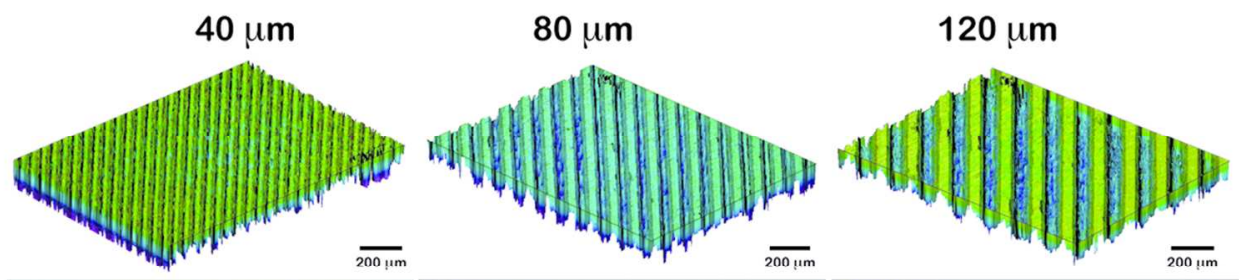

(c)

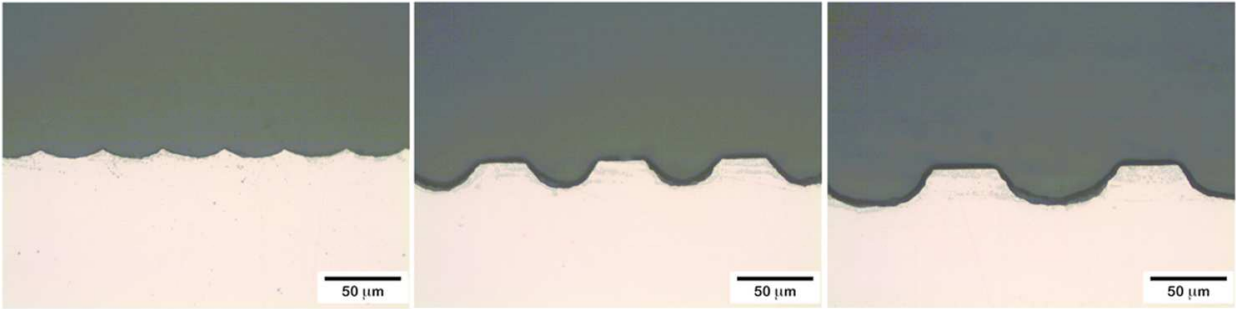

(d)

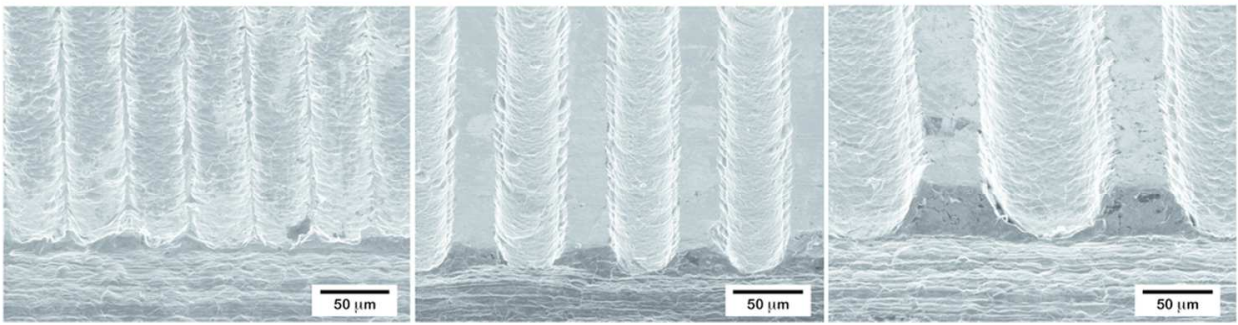

Figure 1

$140 \times 125 \mathrm{~mm}(300 \times 300 \mathrm{DPI})$

John Wiley \& Sons, Inc. 
(a)

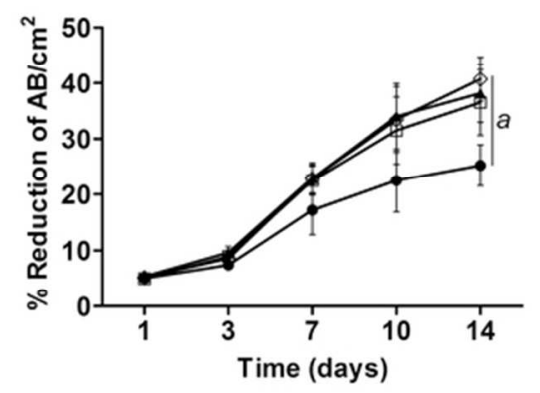

(b)

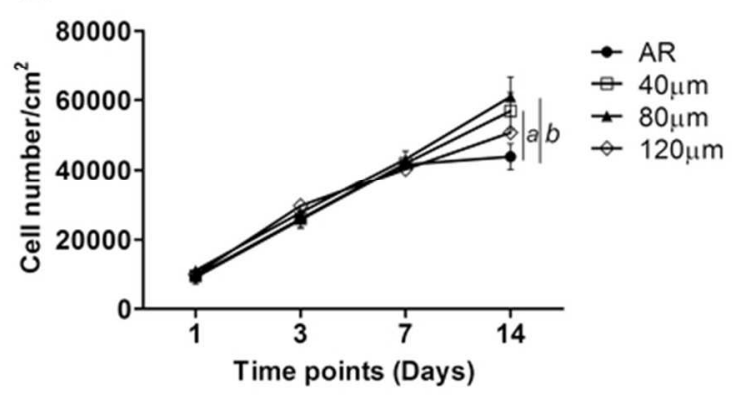

Figure 2

$62 \times 21 \mathrm{~mm}(300 \times 300$ DPI $)$

John Wiley \& Sons, Inc. 


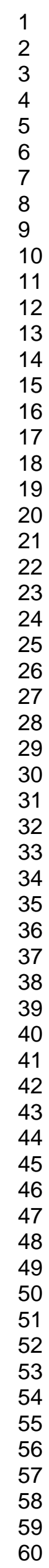

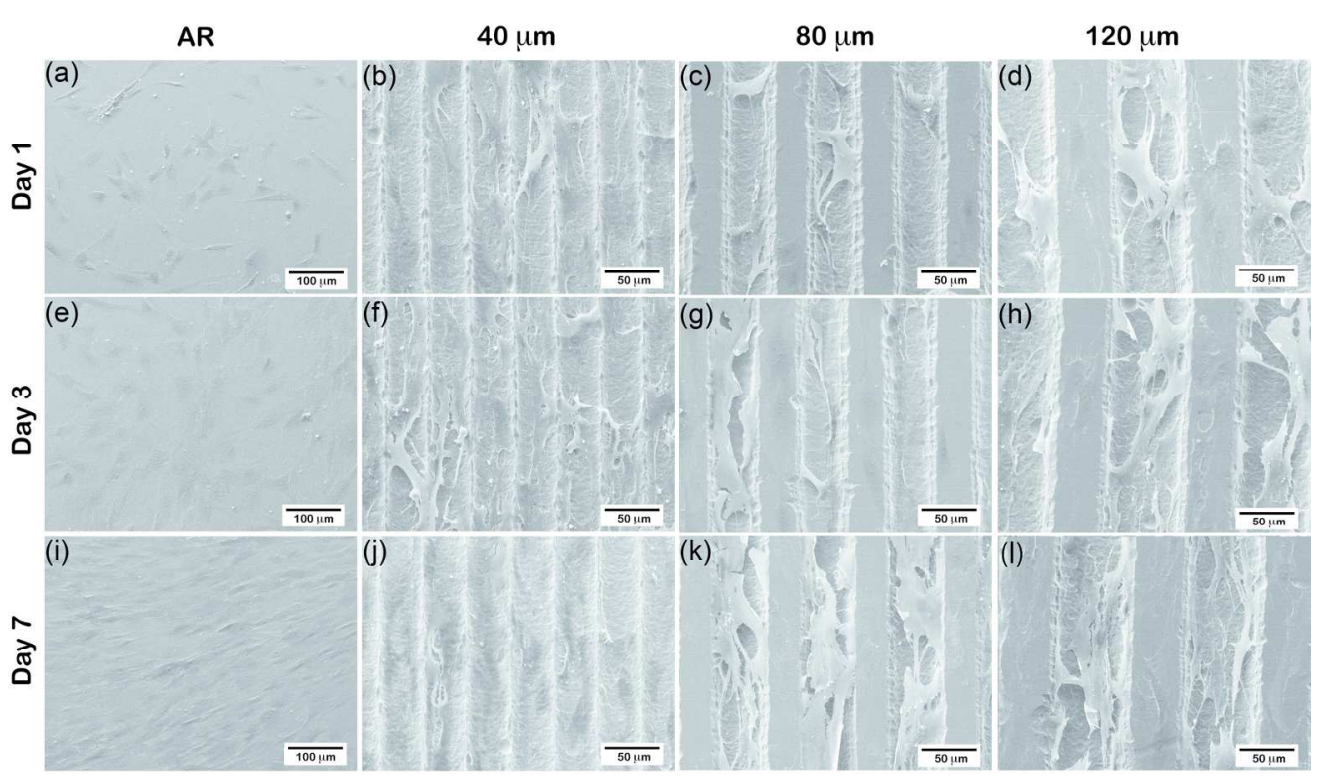

Figure 3

$180 \times 104 \mathrm{~mm}(300 \times 300 \mathrm{DPI})$

John Wiley \& Sons, Inc. 

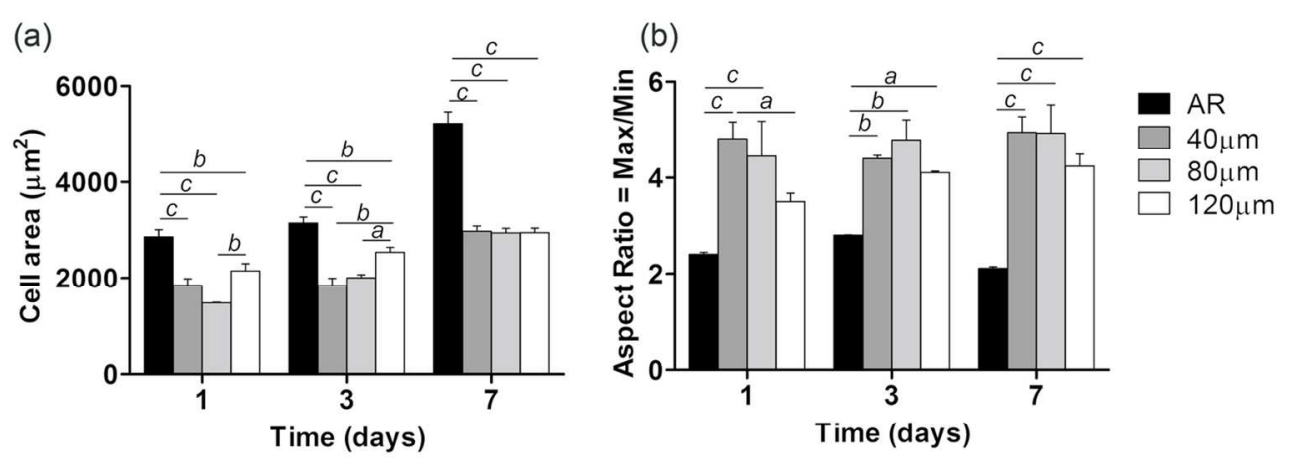

(c)
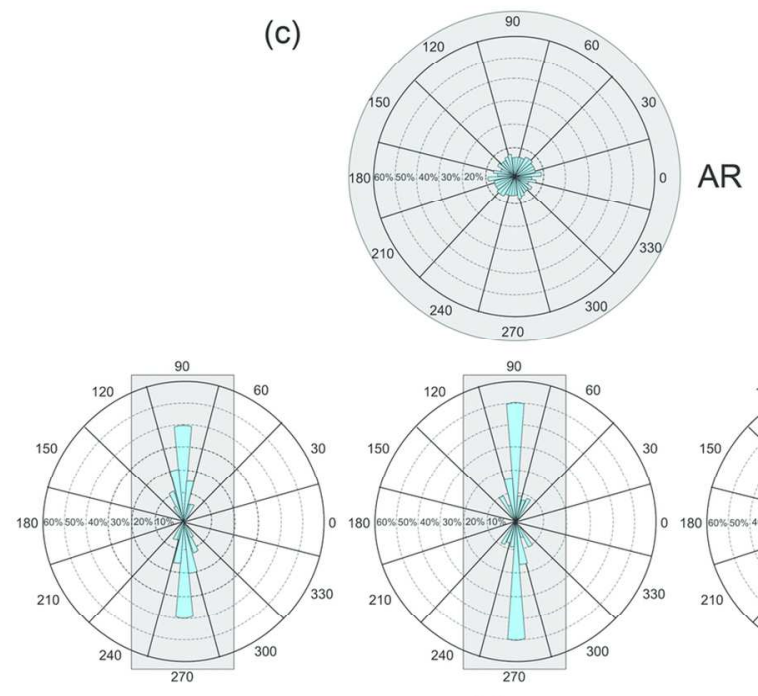

40 um

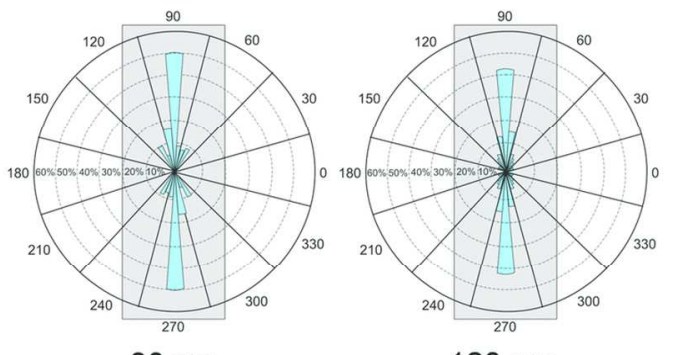

80 um

120 um

Figure 4

$123 \times 118 \mathrm{~mm}(300 \times 300$ DPI $)$

40

41

42

43

44

45

46

47

48

49

50

51

52

53

54

55

56

57

58

59

60

John Wiley \& Sons, Inc. 


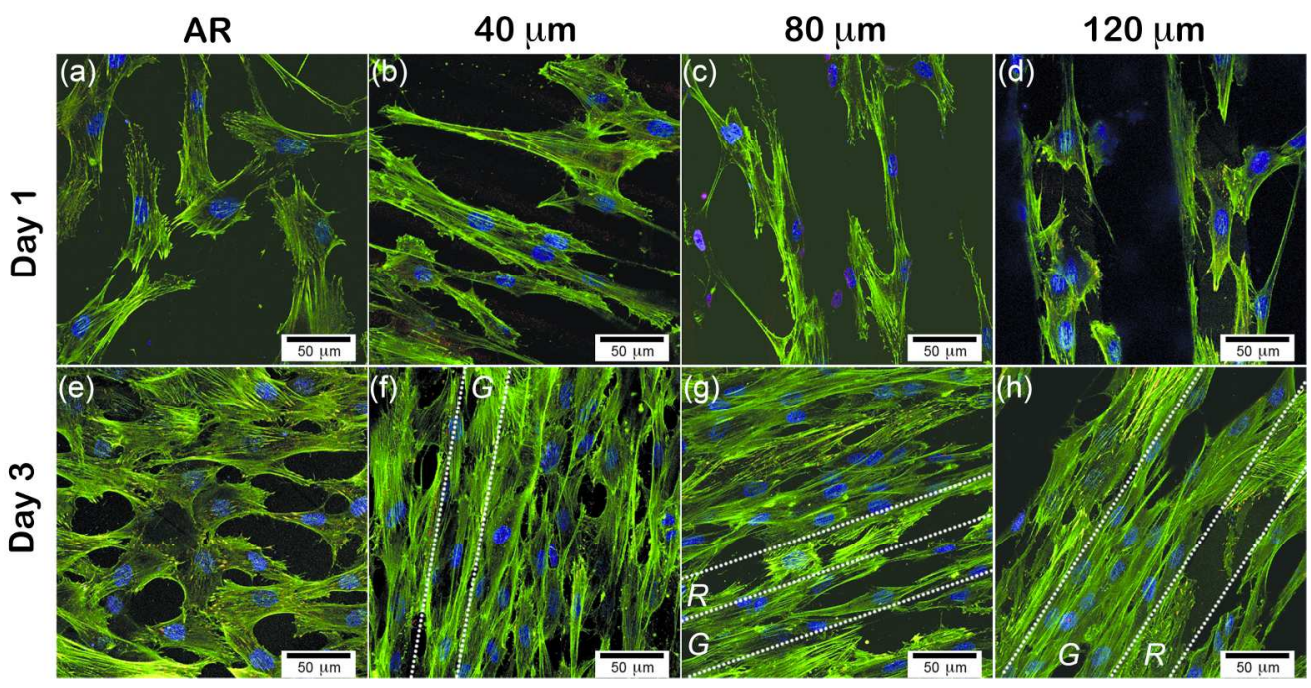

Figure 5

$187 \times 96 \mathrm{~mm}(300 \times 300$ DPI $)$

John Wiley \& Sons, Inc. 

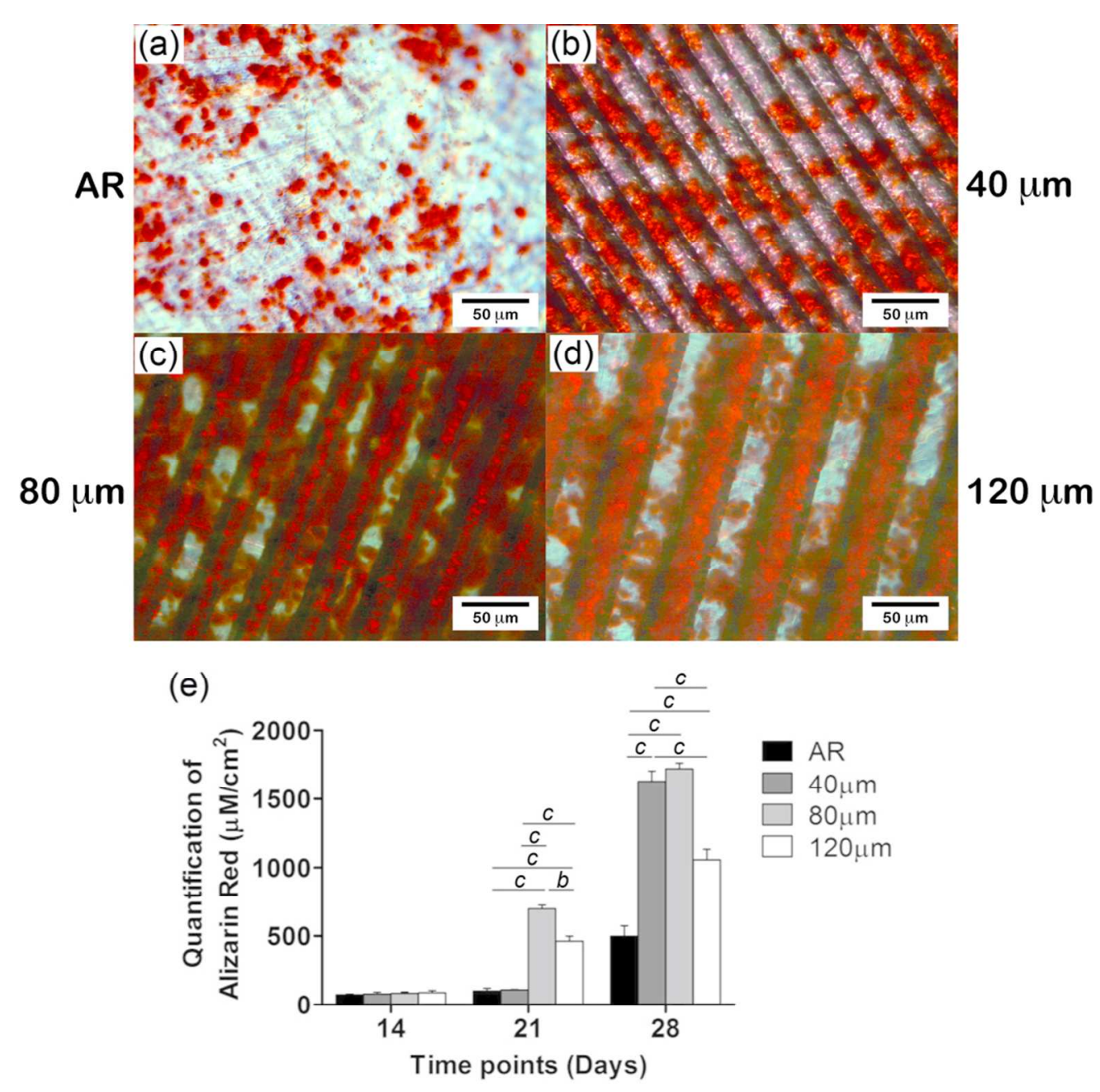

Figure 6

$88 \times 89 \mathrm{~mm}(300 \times 300$ DPI $)$ 


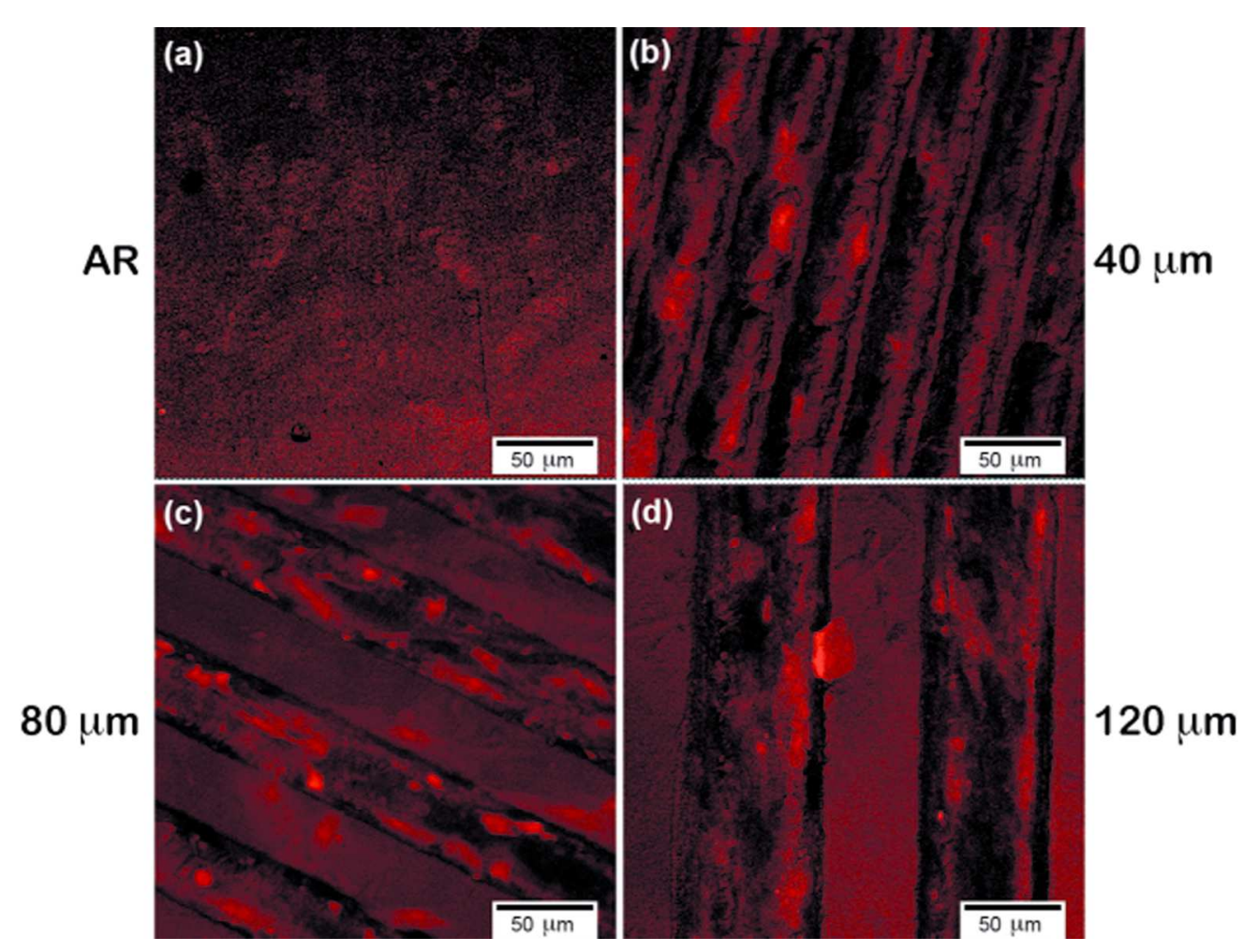

Figure 7

$129 \times 96 \mathrm{~mm}(300 \times 300 \mathrm{DPI})$

John Wiley \& Sons, Inc. 


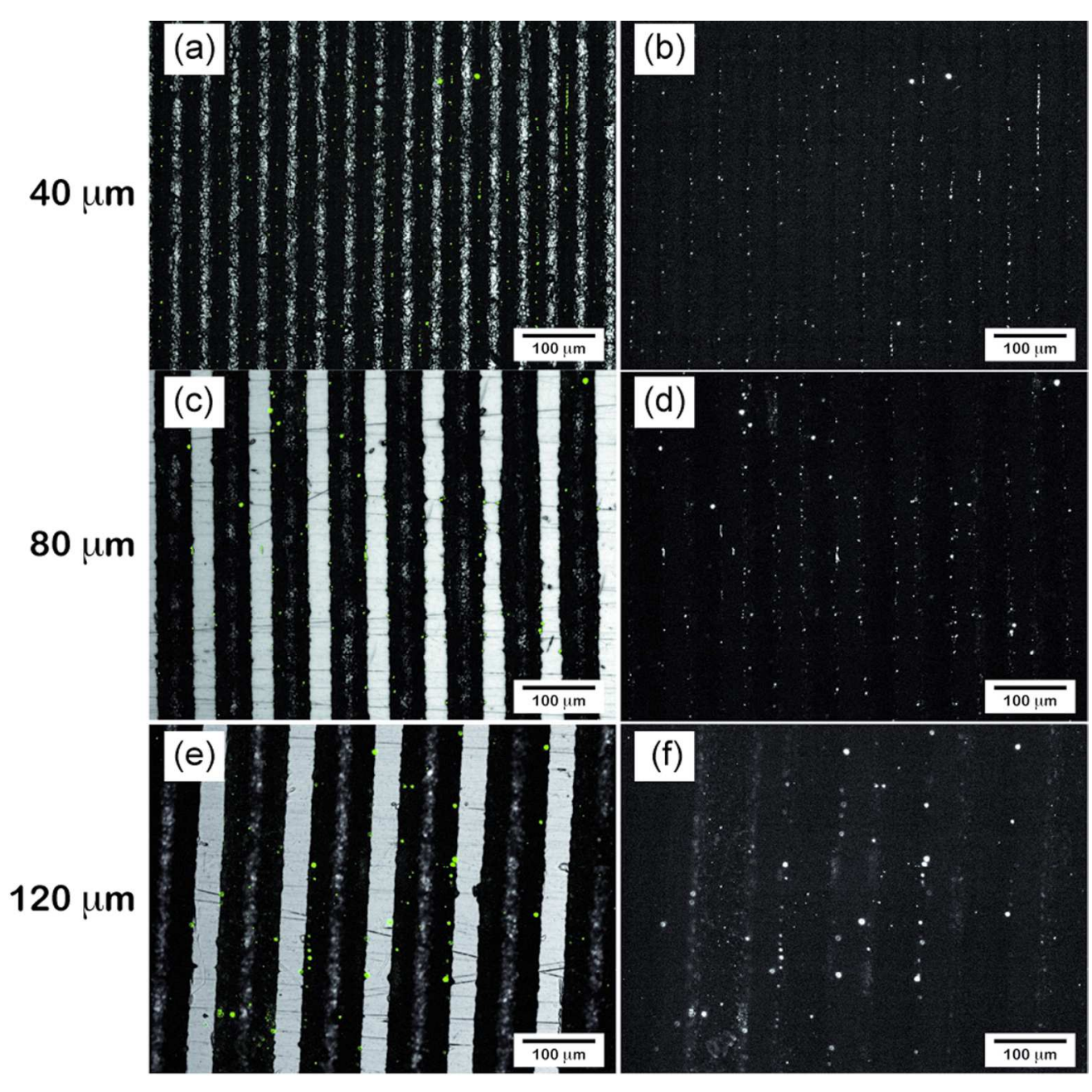

Figure 8

$150 \times 146 \mathrm{~mm}(300 \times 300$ DPI)

John Wiley \& Sons, Inc. 